\title{
Chemotherapeutic Effect of Essential Oil of Wedelia chinensis (Osbeck) on Inducing Apoptosis, Suppressing Angiogenesis and Lung Metastasis in C57BL/6 Mice Model
}

\section{Arumugam Manjamalai and Berlin Grace*}

Department of Biotechnology and Health sciences, Karunya University, India

\begin{abstract}
Aim of the study was to determine the effect of essential oil of Wedelia chinensis (Osbeck) on lung metastasis developed by B16F-10 melanoma cell line in C57BL/6 mice. The essential oil extracted by hydro distillation method was evaluated by GC-MS for its bioactive compounds. Male C57BL/6 mice were injected with B16F-10 melanoma cells through tail vein and simultaneously treated with the essential oil of Wedelia chinensis (Osbeck). The selected dose of drug ( $50 \mu \mathrm{g}$ of essential oil) showed its cytotoxicity on B16 F-10 melanoma cell line with $65.17 \%$ of death within $24 \mathrm{hrs}$ in-vitro. We observed a statistically significant increase in the number of apoptotic cells in essential oil treated group when compared with the normal and cancer control groups. We have also observed an increased level of expression of apoptosis inducing molecules such as p53 and caspase-3 in treated group when compared to cancer group as an indicator of utilization of such molecules for inducing apoptosis. The present investigations indicate the effect of essential oil of Wedelia chinensis (Osbeck) in suppressing the metastatic potential of B16F-10 cells in lungs as well as tumor directed angiogenesis. It has shown a powerful apoptotic effect by increasing the levels of p53 and caspase- 3 enhancing apoptotic nuclei and thereby it inhibits cancer progress. This drug can be therefore taken as a key therapeutic agent to treat cancer in future with extensive molecular studies.
\end{abstract}

Keywords: Wedelia chinensis (Osbeck); Angiogenesis

\section{Introduction}

Cancer is a disease in which abnormal cells divide without control, able to invade other tissues (through the blood and lymph systems), multifactorial in its origin and found to be the second leading cause of death [1]. Deaths due to lung cancer are on rise and the last decade survival rate for lung cancer remains low in spite of the advancements in treatment [2]. Thus, there prevails a growing need for new treatments to be invented. One of the main reasons for the death in cancer patients is due to the ability of tumor cells to metastasize [3].

Angiogenesis is a major pathological component of diseases such as cancer and coronary heart diseases. The normal process of angiogenesis is turned into tumor directed angiogenesis, where the new blood vessels formed due to carcinogens feed cancerous tissues, destroy normal tissue and thereby tumor cells escape into the circulation to lodge in other organs (metastasis) [4].

The hurdle in curing cancer treatment is partly due to lack of targeted therapy at apoptosis (programmed cell death), which plays an essential role in maintaining the tissue homeostasis. Since, the growth of cancer tissue lies in the balance between mitosis and cell death (apoptosis), cancer therapy need to consider the induction of apoptosis in cancer cells as the major target [5].

In the modern era, phytochemical examination of plants having suitable history of use in traditional treatment for diseases often resulted in the isolation of new drugs with anti-tumor activity [6]. Monoterpenes are found in a wide variety of plants and is a major component of their essential oils. Due to the therapeutic efficacy of monoterpenes in experimental model systems, its clinical evaluation has begun for use in treating advanced cancer patients [7].

The study plant Wedelia chinensis (Osbeck) is one such medicinal plant having greater therapeutic value as it is being used traditionally for treating wound healing, hair loss [8] anti-inflammation, analgesic and jaundice [9]. The genus Wedelia consist of approximately 65 species and it is distributed in tropical and warm temperature regions like India, China and Japan [10]. The plant has also scientifically been proven by various researchers that its leaf extract has anti-inflammatory [11] and anti-cancer (Prostate) activities [12]. A highly significant result has been reported by researchers that the carvocrol is very potent inhibitor of cell growth in A549 cell line (human non-small cell lung cancer (NSCLC) cell line). Another report states that the compounds like p-cymene, c-terpinene, b-Caryophyllene, b-bisabolene, carvocrol methyl ether and thymol are compounds having more or less similar biological properties as carvocrol in their action. The B16 F-10 cell line is found to have high potency to metastasize in lung when injected through tail vein [13].

\section{Materials and Methods}

\section{Collection and authentication of plants}

Fresh leaves of Wedelia chinensis (Osbeck) having medicinal value was collected from Western Ghats of siruvani hills of Coimbatore, India. The plant material were taxonomically identified and authenticated by the Botanical Survey of India and the voucher specimen (No.BSI/

${ }^{*}$ Corresponding author: Berlin Grace, Professor and Head of the department Department of Biotechnology and Health sciences, Karunya University, Karunya Nagar, Coimbatore- 641 114, Tamil Nadu, India, Tel: +91- 9677881657; Fax - 91 422 2615615; E-mail: berlingracehead@gmail.com

Received October 11, 2012; Accepted July 15, 2013; Published July 17, 2013

Citation: Manjamalai A, Grace B (2013) Chemotherapeutic Effect of Essential Oil of Wedelia chinensis (Osbeck) on Inducing Apoptosis, Suppressing Angiogenesis and Lung Metastasis in C57BL/6 Mice Model. J Cancer Sci Ther 5: 271-281. doi:10.4172/1948-5956.1000216

Copyright: ( 2013 Manjamalai A, et al. This is an open-access article distributed under the terms of the Creative Commons Attribution License, which permits unrestricted use, distribution, and reproduction in any medium, provided the original author and source are credited. 
SC/5/23/09-10/TECH.1449) is retained in our laboratory for future reference.

\section{Extraction of essential oil}

Extraction of essential oil from the study plant was done by hydro distillation method using clevenger-type apparatus for 3 hours [14]. Plant material (leaves) was immersed directly in a round bottom flask filled with water. This was then brought to boil. Vapours were condensed on a cold surface using condenser attached to it. Essential oil gets separated based on difference in density and immiscibility, is then collected and dried over anhydrous sodium sulphate and stored in a vial at low temperature until analysis.

\section{GC-MS analysis}

GC-MS analysis was performed in Indian Institute of Spices Research (IISR) - Calicut-Kerala - [PMT/IISR/28(13)09] using CARBOWAX capillary column and helium as carrier gas to identify the major compounds present in essential oil [15]. Briefly, $0.2 \mu \mathrm{l}$ of essential oil was injected in to the column of $1 \mu \mathrm{l} / \mathrm{min}$ at $250^{\circ} \mathrm{C}$ and the oven temperature was programmed as $60^{\circ} \mathrm{C}$ for 15 minutes, and then gradually increased to $280^{\circ} \mathrm{C}$ for 3 minutes. The identification was based on comparison of their mass spectra and retention indices.

\section{Experimental animals}

C57BL/6 (20-25 g) of male sex mice (6 animals / group) were purchased from National Institute of Nutrition (Hyderabad, India). The animals were housed in ventilated plastic cages and maintained at 12 hour light / 12 hour dark cycle with free access to food and water. All the experiments involving animals were performed according to the standard protocol and guidelines after getting proper approval from Institutional Animal Ethical Committee.

\section{In vivo acute drug toxicity study}

Overnight-fasted C57BL/6 mice of male sex weighing 20-25 g were divided into 6 groups of 6 animals each. Each group of animals was given different doses of drug (essential oil) such as 50,100, 200, 500, 1000 and $2000 \mu \mathrm{g}$ via i.p. The acute toxicologic effect was observed for 72 hours in terms of mortality [16].

\section{Cell line}

The B16F-10 melanoma cell line was purchased from National Centre for Cell Science (NCCS, Pune, India). The cells were maintained in RPMI 1640 medium buffered with $2 \mathrm{~g} / \mathrm{L}$ of HEPES and sodium bicarbonate, supplemented with dextrose, penicillin, streptomycin and $10 \%$ of fetal bovine serum. The cells were maintained in a humidified atmosphere containing $5 \% \mathrm{CO}_{2}$ at $37^{\circ} \mathrm{C}$. When needed for experiments (or during routine passaging steps), the cells were harvested with trypsin: EDTA (0.05: $0.03[\mathrm{~W} / \mathrm{V}]$ solution, and then washed in phosphate buffered saline (PBS, pH 7.4).

\section{In vitro cytotoxicity study by MTT assay}

This assay is extensively used for measuring cell survival and proliferation. It depends on the cell type, cellular metabolism and incubation time with MTT. This method is based on the capacity of mitochondrial enzyme succinate dehydrogenase of viable cells to reduce the yellow soluble tetrazolium salt MTT [3-(4, 5-dimethyl-thiazole-2yl)-2, 5-diphenyl tetrazolium bromide] into a purple blue insoluble formazan precipitate which is quantified spectrophotometrically after dissolving in DMSO [17]. There is a direct proportionality between the formazan produced and the number of viable cells. Different concentrations of essential oil such as 5, 10, 25 and $50 \mu \mathrm{g} / \mathrm{ml}$ of media were treated with the cell line $\left(1 \times 10^{6}\right)$ and $20 \mu \mathrm{l}$ of MTT $(5 \mathrm{mg} / \mathrm{ml})$ reagent. The test tubes were incubated for $4 \mathrm{hrs}$ at $37^{\circ} \mathrm{C}$. Later $1 \mathrm{ml}$ of DMSO was added to solubilize the formazan crystals and the absorbance was taken at $570 \mathrm{~nm}$. The percent specific cytotoxicity was calculated expressed as percentage of viable cells.

\section{In vivo anti-cancer study using $\mathrm{B} 16 \mathrm{~F}-10$ cell line}

The effect of essential oil on suppressing the lung metastasis was studied using male C57BL/6 mice which were injected through tail vein with $1 \times 10^{6} / 0.1 \mathrm{ml} \mathrm{B16F-10}$ mouse melanoma cells having high metastasis activity from small inoculums [18]. Animals were divided into 4 groups of 6 mice in each group. Group 1 normal mice were left as such without any treatment. Group 2 cancer controls in which cancer cells were injected to develop cancer in mice and were left without any treatment. Group 3 vehicle controls injected with cancer cells and were treated with $0.1 \mathrm{ml}$ of $50 \%$ of ethanol. Group 4 essential oil treated group injected with cancer cells and were treated with $0.1 \mathrm{ml}$ of $50 \mu \mathrm{g}$ of essential oil of Wedelia chinensis (Osbeck) for 21 days after cell line injection. The brief experimental design is given below,

\section{Experimental design (6 mice/group)}

Group 1: Normal mice

Group 2: Cell line alone

Group 3: Cell line + vehicle treated

Group 4: Cell line + essential oil treated

\section{Body weight and lung weight in the experimental animals}

The body weight and lung weight were noted on the initial and final $\left(22^{\text {nd }}\right)$ day in all the experimental groups. The values are expressed in mean of all the six mice in a group.

\section{Tumor nodule count}

On the $22^{\text {nd }}$ day after scarification their lungs were excised, weighed, and placed in phosphate-buffered saline (PBS, pH 7.4). The number of lung tumor nodules on the surface of the lung was counted and the percentage inhibition of lung tumor nodule formation was calculated [19].

\section{Haematological changes}

Blood was collected from all mice by cardiac puncture after scarification on $22^{\text {nd }}$ day and the blood parameters such as hemoglobin $(\mathrm{Hb})$ and white blood cells (WBC) were observed in all the groups [20]

\section{Histopathological analysis of lung}

Lung tissues (tumor nodules) were dissected out after scarification of mice, fixed in $10 \%$ formaldehyde, dehydrated and embedded in paraffin wax for histological studies. From the blocks, $4 \mu \mathrm{m}$ sections were then stained with Hematoxylin and Eosin ( $\mathrm{H} \& \mathrm{E})$, mounted in DPX and examined under a microscope for histopathological changes of lung cancer [21].

\section{Study of apoptosis by TUNEL assay}

Terminal deoxynucleotidyl transferase-mediated dUTP nick end- 
Citation: Manjamalai A, Grace B (2013) Chemotherapeutic Effect of Essential Oil of Wedelia chinensis (Osbeck) on Inducing Apoptosis, Suppressing Angiogenesis and Lung Metastasis in C57BL/6 Mice Model. J Cancer Sci Ther 5: 271-281. doi:10.4172/1948-5956.1000216

labeling (TUNEL) was performed with in situ apoptosis detection kit (Promega Corporation, 2800 Woods Hollow Road, Madison, USA) following the manufacturer's instructions [22]. Briefly, the deparaffinized tissue section in xylene was washed in $100 \%$ ethanol for 5 minutes. Then the samples were rehydrated by sequentially graded ethanol washes $(100 \%, 95 \%, 85 \%, 70 \%$, and $50 \%)$ for 3 minutes each at room temperature. Again washed the samples, by immersing the slides in $0.85 \% \mathrm{NaCl}$ and in PBS for 5 minutes. Fixed the tissue sections by immersing the slides in $4 \%$ methanol free formaldehyde solution in PBS for 15 minutes at room temperature and washed in PBS for 5 minutes. Added $100 \mu \mathrm{l}$ of the $20 \mu \mathrm{g} / \mathrm{ml}$ proteinase $\mathrm{K}$ to each slide to cover the tissue section and incubated for 8-10 minutes. Proteinase $\mathrm{K}$ helps permeabilize tissues and cells to the staining reagents in subsequent steps. After washing with PBS fixed the tissue sections by immersing the slides in $4 \%$ methanol-free formaldehyde solution in PBS for 5 minutes at room temperature and again washed with PBS. Then the sections were incubated in equilibration buffer for 10 minutes and added $100 \mu \mathrm{l}$ of rTdT reaction mix (Equilibration buffer $98 \mu \mathrm{l}$ + biotinylated Nucleotide mix $1 \mu \mathrm{l}+\mathrm{rTdT} 1 \mu \mathrm{l})$ for all slides. Finally, after the incubation, $100 \mu \mathrm{l}$ of Streptavidin HRP solution (1:500 in PBS) was added $100 \mu \mathrm{l}$ to each slide and incubated for 30 minutes. Then added $100 \mu \mathrm{l}$ of DAB solution to each slide and kept until a light brown background was developed. After mounting the slides with DPX the stained cells were examined at $40 \mathrm{x}$ magnification by using a light microscope (Olympus BH-2). Cell death was quantitated by counting 200 cells in five to seven separate fields of view per slide and noting the percentage of apoptotic cells based on morphological appearance.

\section{Immunodetection of p53 and Caspase - 3 expressions in lung} tissue

The level of expression of p53 and caspase 3 was checked by immunohistochemistry using immunofluorescence [23]. Briefly, frozen tissue sections $(16 \mu \mathrm{m})$ of tumor sample and normal were fixed with acetone for 20 minutes followed by permeabilization with $0.5 \%(\mathrm{v} / \mathrm{v})$ Triton $\times 100$ in PBS for 10 minutes at room temperature. After blocking with 5\% horse serum in PBS for 1 hour, the sections were incubated with primary antibody [mouse monoclonal antibodies to p53 and caspase 3 (Santa Cruz Biotechnology, USA] for 1 hour and then incubated with
FITC conjugated secondary antibody for 1 hour at room temperature. To reduce auto fluorescence, the sections were treated with $\mathrm{CuSO} 4$ $(10 \mathrm{mM})$ in ammonium acetate buffer (50mM CH3COONH4, $\mathrm{pH} 5.5)$ for 30 minutes. The sections were counterstained with DAPI - (4', 6 diamidino - 2 - phenylindole) for 5 minutes and mounted in vector shield (Vector laboratories). The normal and tumor sections treated as above, but without primary antibody, served as negative control. After mounting the slides, the section were viewed for immunofluorescence under a confocal laser scanning immunofluorescence microscopy (CLSM) using a Zeiss LSM 510 META confocal microscope. Image analysis was done using LSM510 META software (Carl Zeiss) and images were assembled using adobe Photoshop 7.0.

\section{Study of tumor directed angiogenesis by the assay of new capillary vessel formation}

C57BL/6 mice were divided into three groups and each group contains six mice. In brief, B16F-10 cells $\left(1 \times 10^{6}\right)$ were injected intradermally on the shaven ventral skin of each mouse [24]. Drug (50 $\mu \mathrm{g} /$ dose) was given through IP for 10 days after cell line injection in which group 1 receives no treatment left as mice injected with cancer cells alone, group 2 was injected with cancer cells and receives vehicle 0.1 $\mathrm{ml}$ of $50 \%$ ethanol and group 3 the drug treatment group was injected with cancer cells and receives $0.1 \mathrm{ml}$ of $50 \mu \mathrm{g}$ of essential oil of Wedelia chinensis (Osbeck) and mice were sacrificed on the eleventh day. The skin from the ventral side was dissected out, washed with phosphate buffered saline and the number of tumor directed capillaries was counted using a dissection microscope. The percentage of inhibition of capillaries formation was also calculated using the formula as follows,

$\%$ inhibition $=$ Tumor directed capillaries of cancer control Tumor directed capillaries of treated mice / Tumor capillaries of cancer control $\times 100$.

\section{Statistical analysis}

Data was statistically analyzed using one - way ANOVA as primary test followed by Dunnett's test one way ANOVA, using Graph pad InStat3.0 software. All the results were expressed as mean \pm S.D of 6 animals in each group and considered significant when $\mathrm{P} \leq 0.05$.

\begin{tabular}{|c|c|c|c|c|c|c|c|c|c|}
\hline $\begin{array}{c}\text { Peak S. } \\
\text { No }\end{array}$ & Retention Time & Initial Time & Final Time & Area & Area\% & Height & Height\% & $\begin{array}{c}\text { Area/ } \\
\text { Height }\end{array}$ & Name of the compound \\
\hline 1 & 3.077 & 3.008 & 3.142 & 2262359 & 7.29 & 766572 & 15.49 & 2.95 & \\
\hline 2 & 5.863 & 5.808 & 5.917 & 74913 & 0.24 & 27661 & 0.56 & 2.70 & $\beta$-myrcene \\
\hline 3 & 6.273 & 6.208 & 6.317 & 193397 & 0.62 & 71627 & 1.45 & 2.70 & $\alpha$-terpinene \\
\hline 4 & 8.304 & 8.192 & 8.358 & 1416392 & 4.57 & 396503 & 8.01 & 3.57 & $\gamma$-terpinene \\
\hline 5 & 9.063 & 8.942 & 9.108 & 2709933 & 8.73 & 682275 & 13.78 & 3.97 & Ortho-lymene \\
\hline 6 & 18.756 & 18.633 & 18.783 & 1837973 & 5.92 & 487288 & 9.84 & 3.77 & $\alpha$-bergamotene \\
\hline 7 & 18.959 & 18.783 & 19.025 & 4600145 & 14.83 & 703940 & 14.22 & 6.53 & T-Caryophyllene \\
\hline 8 & 21.097 & 20.950 & 21.158 & 1765457 & 5.69 & 364894 & 7.37 & 4.83 & $\alpha$-humulene \\
\hline 9 & 23.067 & 23.008 & 23.133 & 124813 & 0.40 & 38341 & 0.77 & 3.25 & - \\
\hline 10 & 31.209 & 31.067 & 31.275 & 1421838 & 4.58 & 257366 & 5.20 & 5.52 & Aromadendrene \\
\hline 11 & 33.017 & 32.950 & 33.092 & 147489 & 0.48 & 31423 & 0.63 & 4.69 & 3 -decynex \\
\hline 12 & 37.775 & 37.708 & 37.850 & 178970 & 0.58 & 43393 & 0.88 & 4.12 & Thymol \\
\hline 13 & 38.668 & 38.492 & 38.867 & 1429387 & 46.07 & 107896 & 21.80 & 13.24 & Carvocrol \\
\hline
\end{tabular}

Table 1: GC - MS peak report for the essential oil of Wedelia chinensis (Osbeck). 

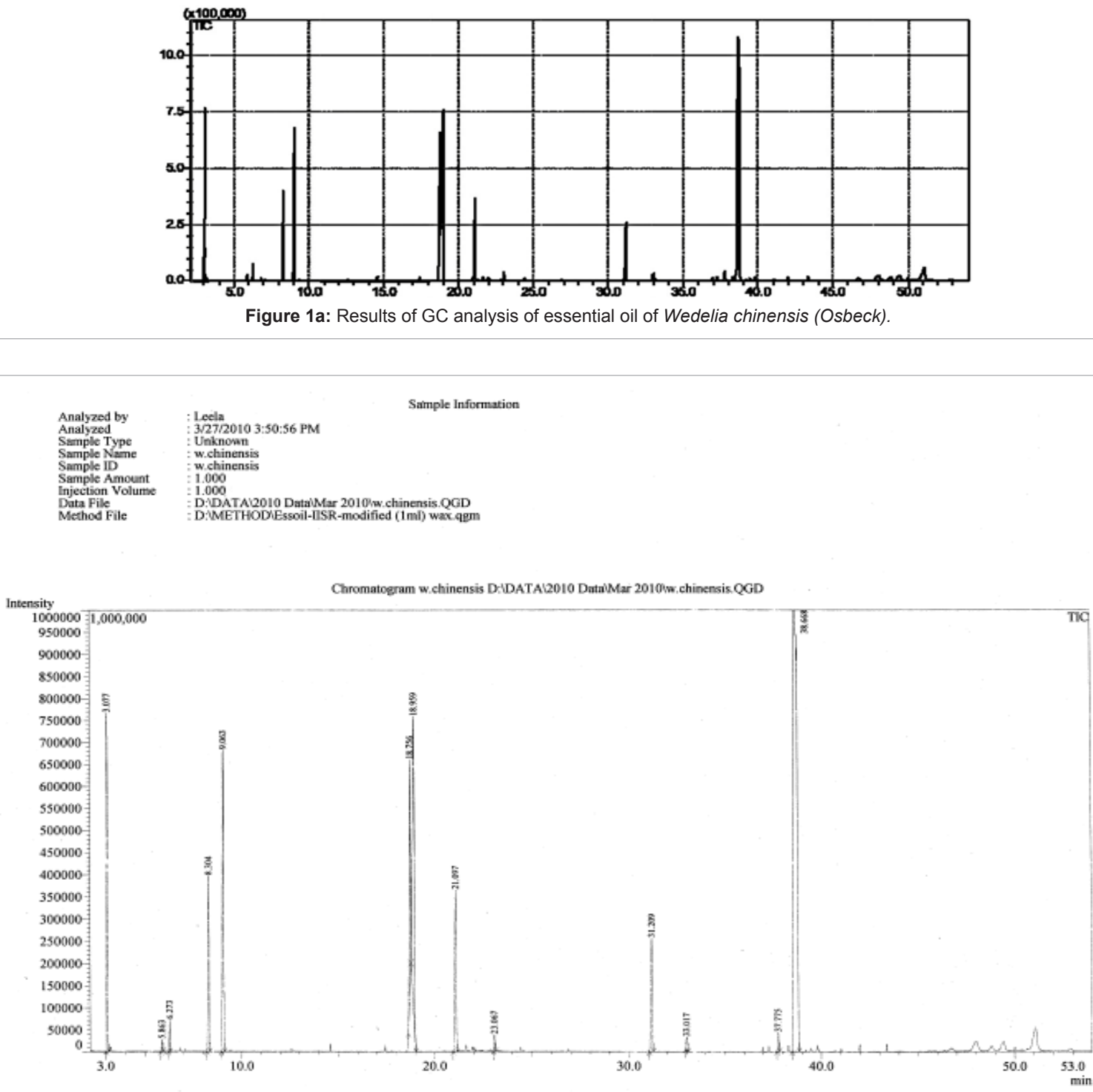

Figure 1b: Results of GC-MS analysis of essential oil of Wedelia chinensis (Osbeck).

\section{Results}

\section{Phytochemicals identified in essential oil by GC-MS analysis}

Table 1 and Figures 1a and 1b shows the GC and GC-MS analysis of the essential oil of Wedelia chinensis (Osbeck) we found that the oil contains 11 compounds namely $\beta$-myrcene, $\alpha$-terpinene, $\gamma$-terpinene, Ortho-lymene, a-bergamotene, Trans Caryophyllene, a-humulene, Aromadendrene, 3-decynex, Thymol and Carvocrol. Out of these compounds Carvocrol and Trans - Caryophyllene were found to be the major compounds with $96 \%$ similarity with Wiley and NBS library.

\section{In vivo acute drug toxicity and in vitro cytotoxicity}

The acute drug toxicity study has shown that even the higher dosage of $2000 \mu \mathrm{g}$ did not show any observable toxic effects in C57BL/6 mice. However, an optimal dose of $50 \mu \mathrm{g}$ was used for all our in vivo studies which would be much lower than the $\mathrm{IC}_{50}$ value. As shown in Figure 2, in vitro cytotoxicity study has shown that the $50 \mu \mathrm{g}$ of the essential oil of
Wedelia chinensis (Osbeck) exhibited $65.17 \%$ of cancer cell (B16 F-10) death within $24 \mathrm{hrs}$

\section{Body and lung weight of experimental groups}

We have observed a significant difference in the body and lung weight of mice among the groups as shown in Figure 3. The initial mean body weight of tumor induced mice was $21.38 \pm 0.18$ and on the final $22^{\text {nd }}$ day it was found to be decreased $(19.81 \pm 0.19)$ whereas, in essential oil treated group it was found to be increased on final day $(21.32 \pm 0.22)$ from initial day $(20.85 \pm 0.21)$. The relative lung weight of the normal mice was found to be $(2.31 \pm 0.02)$ and it was found to be increased in the tumor induced group $(3.22 \pm 0.06)$ whereas, in the treated group it was found to be significantly decreased $(2.65 \pm 0.03)$.

\section{Tumor nodule count}

Table 2 shows the percentage inhibition of tumor nodule formation in which a high percentage of inhibition $66.80 \%$ was found in the mice treated with the essential oil of Wedelia chinensis (Osbeck) when 
Citation: Manjamalai A, Grace B (2013) Chemotherapeutic Effect of Essential Oil of Wedelia chinensis (Osbeck) on Inducing Apoptosis, Suppressing Angiogenesis and Lung Metastasis in C57BL/6 Mice Model. J Cancer Sci Ther 5: 271-281. doi:10.4172/1948-5956.1000216

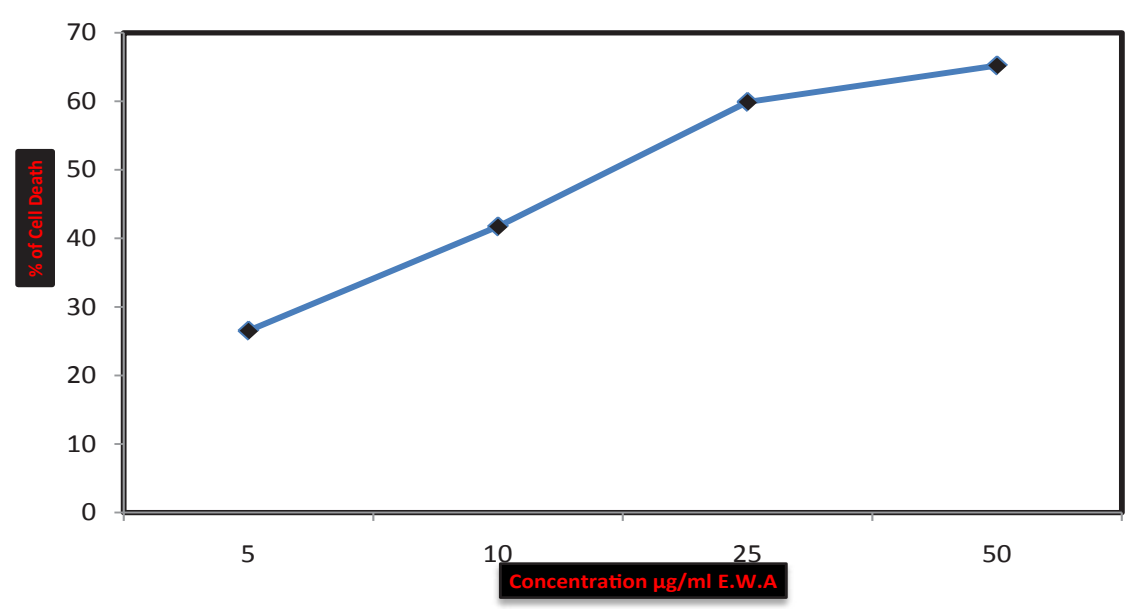

E.W.C- Essential oil of Wedelia chinensis (Osbeck)

Figure 2: In vitro cytotoxicity activity of essential oil towards B16F-10 cell line by MTT assay.

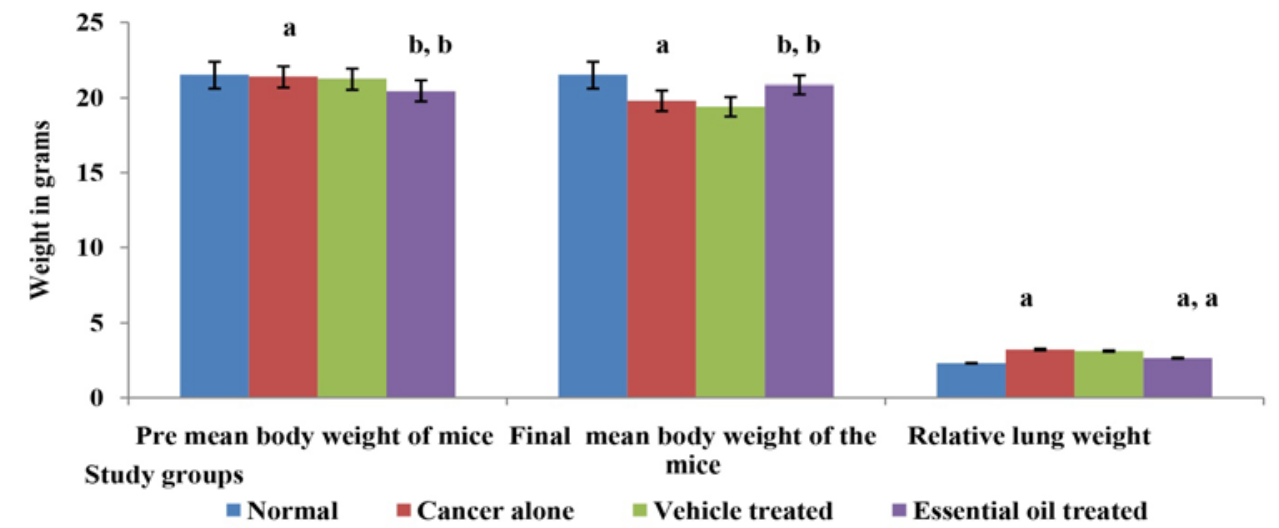

Figure 3: Effect of essential oil of Wedelia chinensis (Osbeck) on body and relative lung weight of experimental groups.

\begin{tabular}{|l|l|l|}
\hline Group & Number of tumor nodules / lung & \% Inhibition of tumor nodules \\
\hline Group 1: & - & - \\
\hline Group 2: & 157.66 & - \\
\hline Group 3: & \pm 2.81 & - \\
\hline Group 4: & 156.66 & 66.80 \\
\hline 1.03 & 52.33 \\
\hline $4.63^{\text {a }}$ & \\
\hline
\end{tabular}

Data are expressed as mean \pm S.D.

Group 2 Vs Group 4 [a - P $\leq 0.01]$

Table 2: Effect of essential oil of Wedelia chinensis (Osbeck) in the percentage inhibition of lung tumor nodule formation.

compared with cancer induced group. The number of tumor nodules found in cancer group is $157.66 \pm 2.81$ and that of in the treated group is $52.33 \pm 4.63$.

\section{Hematological parameters}

Figure $4 \mathrm{a}$ shows the level of $\mathrm{WBC}$ on the $22^{\text {nd }}$ day. It was found to be $(7325 \pm 17.60)$ in the normal mice and $(7135 \pm 17.65)$ in the essential oil treated groups. On the other hand WBC was found to be high $(7443$ $\pm 25.23)$ in the tumor control mice. Similarly, on the $22^{\text {nd }}$ day, the hemoglobin level in gram percentage also was found to be increased $(13.65 \pm 0.12)$ in the essential oil treated group when compared with tumor control groups $(11.25 \pm 0.21)$ as shown in the Figure $4 \mathrm{~b}$.

\section{Histopathological changes}

The Hematoxylin and Eosin stained sections of lung tissues are shown in Figure 5. The lung from healthy normal mice shows normal architecture of lungs with bronchioles, alveoli and interstitium (Figure 5a). Lungs of tumor control (cancer alone) showed a massive cell proliferation around the bronchioles and infiltration of metastatic colonies of melanoma in the interstitium of the lung. Increased fibrosis reduces alveolar space, which leads to reduction in vital capacity of the lung. Multiple area of necrosis with infiltration of neutrophils appeared 
Citation: Manjamalai A, Grace B (2013) Chemotherapeutic Effect of Essential Oil of Wedelia chinensis (Osbeck) on Inducing Apoptosis, Suppressing Angiogenesis and Lung Metastasis in C57BL/6 Mice Model. J Cancer Sci Ther 5: 271-281. doi:10.4172/1948-5956.1000216

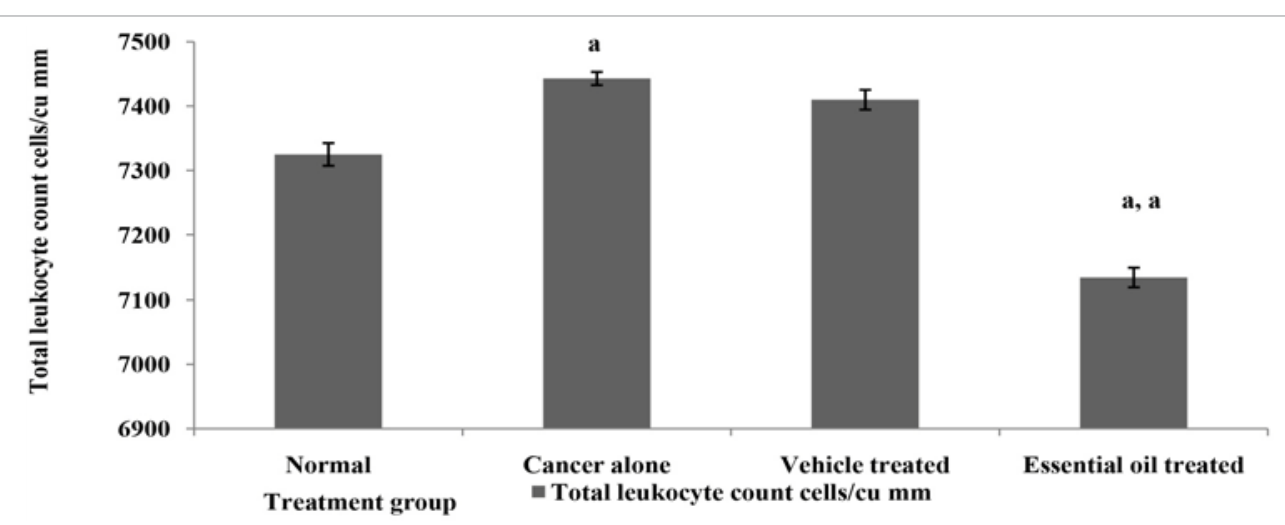

Figure 4a: Effect of essential oil of Wedelia chinensis (Osbeck) on total leukocyte count (WBC) and haemoglobin level.

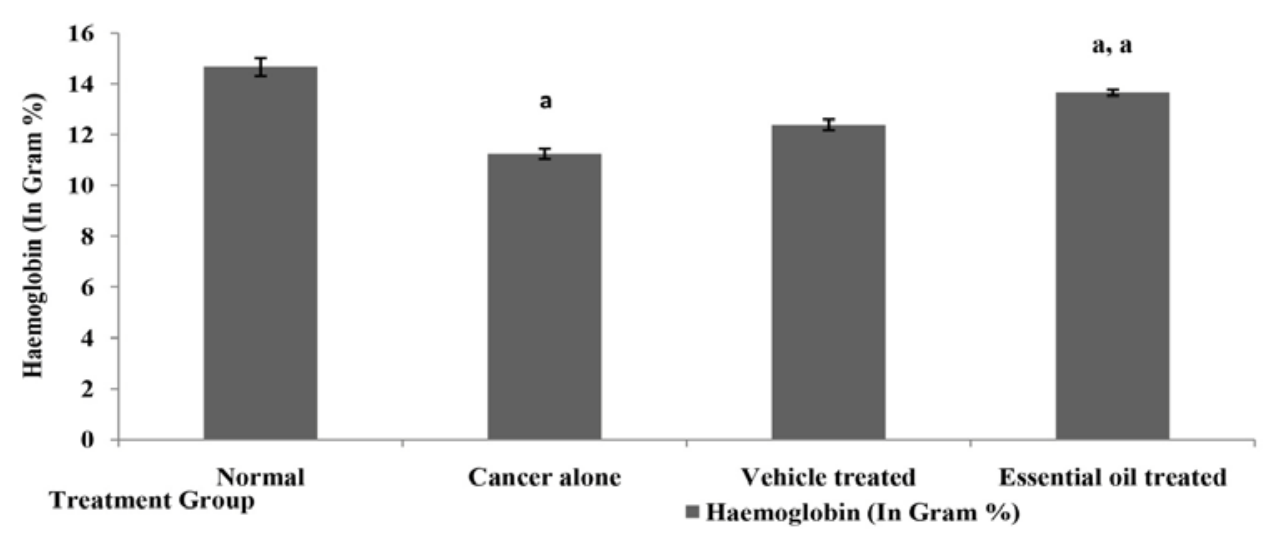

Figure 4b: Effect of essential oil of Wedelia chinensis (Osbeck) on total leukocyte count (WBC) and haemoglobin level.
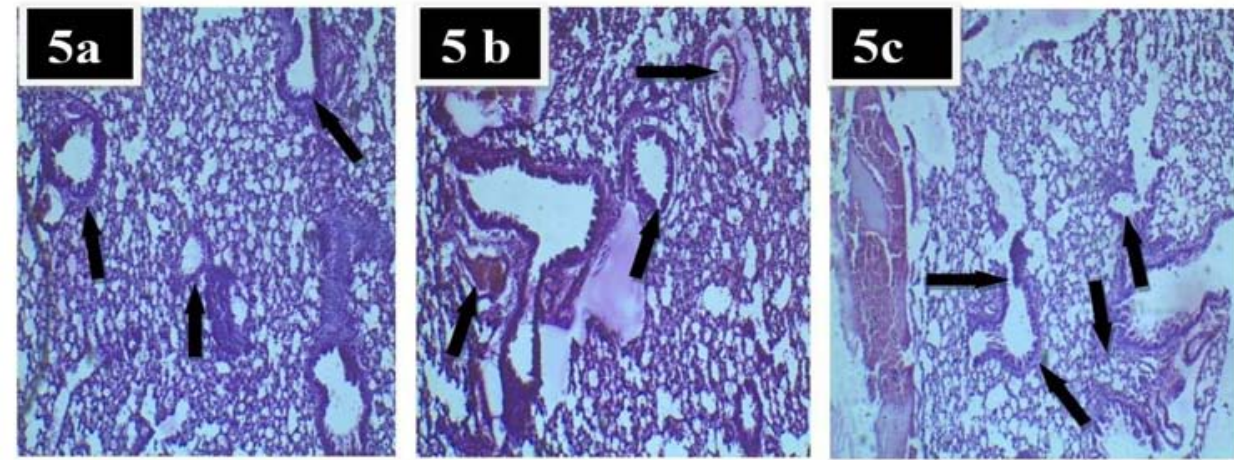

Figure 5: Histopathological analysis of lung tissue. 5a-Normal mice - [Shows normal architecture of lungs with bronchioles, alveoli and interstitium]. 5b-lung of mice injected with B16F-10 cell line (cancer alone) - [Shows massive abnormal cell growth around the bronchioles and infiltration of melanoma in the interstitium of the lung, coarse granules of black melanin pigment are seen both inside the macrophages as well as outside them]. 5c-lung of treated group shows significant reduction in tumor mass and regeneration of alveolar passage with ciliated columnar epithelial cells and reduced metastatic foci in lungs showing luminal epithelial-like morphology with well differentiated secretory glands are seen and reduction in the coarse granules of black melanin pigment are also seen.

in between and within lobules. Entire alveolar region of lungs were occupied by multiple lobes of tubular neoplastic cells. Coarse granules of black melanin pigments were observed in the cells/tissue. The field focused shows necrosed and congested alveoli with dense acute and chronic inflammatory cells (Figure 5b). Simultaneous administration of essential oil of Wedelia chinensis (Osbeck) (Figure 5c) at $50 \mu \mathrm{g}$ showed significant reduction in tumor mass and regeneration of alveolar passage with ciliated columnar epithelial cells. Lungs showing luminal epithelial like morphology with well differentiated secretory glands.

\section{Level of apoptosis by TUNEL assay}

We have observed an increase in the number of apoptotic cells with mean apoptotic nuclei of $27.83 \pm 1.16$ in treated mice which is significantly higher when compared with that of in the normal mice $5.33 \pm 1.51$ and cancer control $13 \pm 1.26$ respectively. The data is shown 


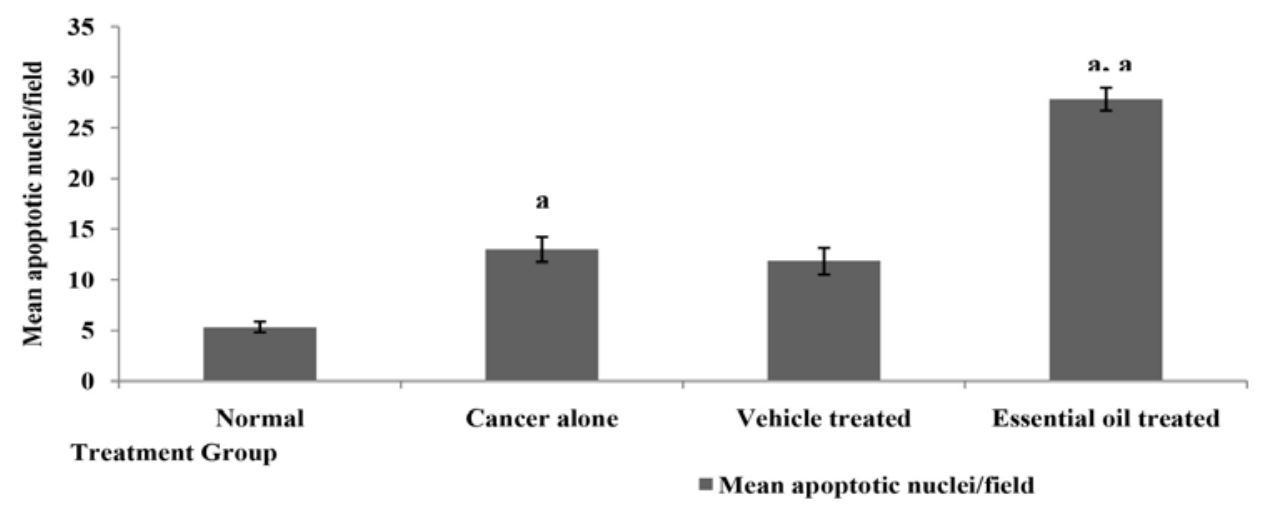

Figure 6: Levels of apoptosis by TUNEL assay.
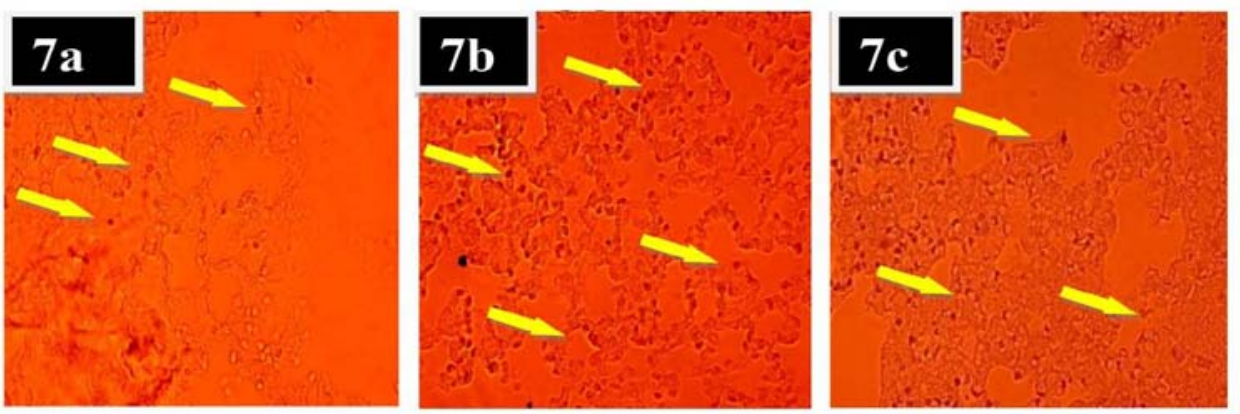

Figure 7: Level of apoptosis by TUNEL assay. 7a-Normal lung section showing the minimal number of apoptotic cells which exist in normal growth cycle. 7b-Lung section of mice injected with B16F-10 cell line (cancer alone) showing a moderated number of apoptotic cells due to enhanced proliferation. 7c- Lung section of treated mice with the essential oil Wedelia chinensis (Osbeck). Shows enhanced apoptotic cells when compared with cancer alone case. [Arrow indicates the dark brown color stained positive apoptotic nuclei].

in Figure 6 and the apoptotic nuclei staining are shown in Figures 7a$7 \mathrm{c}$.

\section{Immunoflouresence for p53 and Caspase 3 expressions}

Examination of the expression of $\mathrm{p} 53$ and caspase 3 was performed using confocal microscope. Lower expression of p53 and caspase 3 were found in the neoplastic epithelial cells of all the sections of cancer group when compared with the normal lung tissue. Expressions of p53 and caspase 3 in the essential oil treated group were found to be increased when compared with the cancer control. Not much immunofluorescence was observed in the normal mice for both p53 and caspase 3 proteins as shown in Figures $8 a-8 c$ and Figures $9 a-9 c$.

\section{Level of tumor directed capillary vessel formation}

Table 3 shows the level of capillary vessel formation in C57BL/6 mice upon induction with B16 F-10 cell line. The result shows that the essential of Wedelia chinensis (Osbeck) exhibit a significant and high percentage of inhibition in formation of tumor directed new blood vessels accounting for $19.32 \%$.

\section{Discussion}

In the unexplored nature there are thousands of complex molecules synthesized by plants of both higher and lower orders that are not known to biochemists. In general, Phytochemicals are naturally occurring, biologically active chemical compounds with diseasepreventive property particularly for some forms of cancers and heart diseases. Recent research interest on medicinal plants has opened an opportunity to study the effectiveness of medicinal plants on treating dreadful cancer at molecular level.

The essential oil of Wedelia chinensis (Osbeck) contains 10 compounds, in which Carvocrol $\left(\mathrm{C}_{6} \mathrm{H}_{12} \mathrm{O}_{6}\right)$ and t-Caryophyllene $\left(\mathrm{C}_{15} \mathrm{H}_{24}\right)$ were found to be the major compounds belong to the monoterpene family [25]. Carvocrol has been reported strongly for its antibacterial [26], anti-inflammatory [27] and anti-oxidant activities [28]. A recent study carried out using carvocrol has reported that it has the ability to stimulate apoptosis in prostate cancer cells. On the other hand, researches have reported the possible synergistic effect of carvocrol with other monoterpenes, sesquiterpenes like caryophyllene. All these studies have proven with scientific evidence that the terpenes or a mixture of terpenes are the potential inducers of apoptosis in cancer cells [29].

The in-vivo drug toxicity study has shown that the essential oil even in its higher dosage of $2000 \mu \mathrm{g}$ is not lethal to C57BL/6 mice. The essential oil of Wedelia chinensis (Osbeck) was found to be very effective in killing B16F-10 cell line in a dose dependent manner as observed in the in-vitro cytotoxicity assay (MTT Assay) with $65.17 \%$ of cancer cell death within $24 \mathrm{hrs}$ for $50 \mu \mathrm{g}$. Hence, this is the first positive outcome of our study that the essential oil of our study plant has good ability to kill cancer cells.

Among all the cancers known, lung cancer is the one which is characterized by rapid metastasis and frequent resistant to current 
Citation: Manjamalai A, Grace B (2013) Chemotherapeutic Effect of Essential Oil of Wedelia chinensis (Osbeck) on Inducing Apoptosis, Suppressing Angiogenesis and Lung Metastasis in C57BL/6 Mice Model. J Cancer Sci Ther 5: 271-281. doi:10.4172/1948-5956.1000216
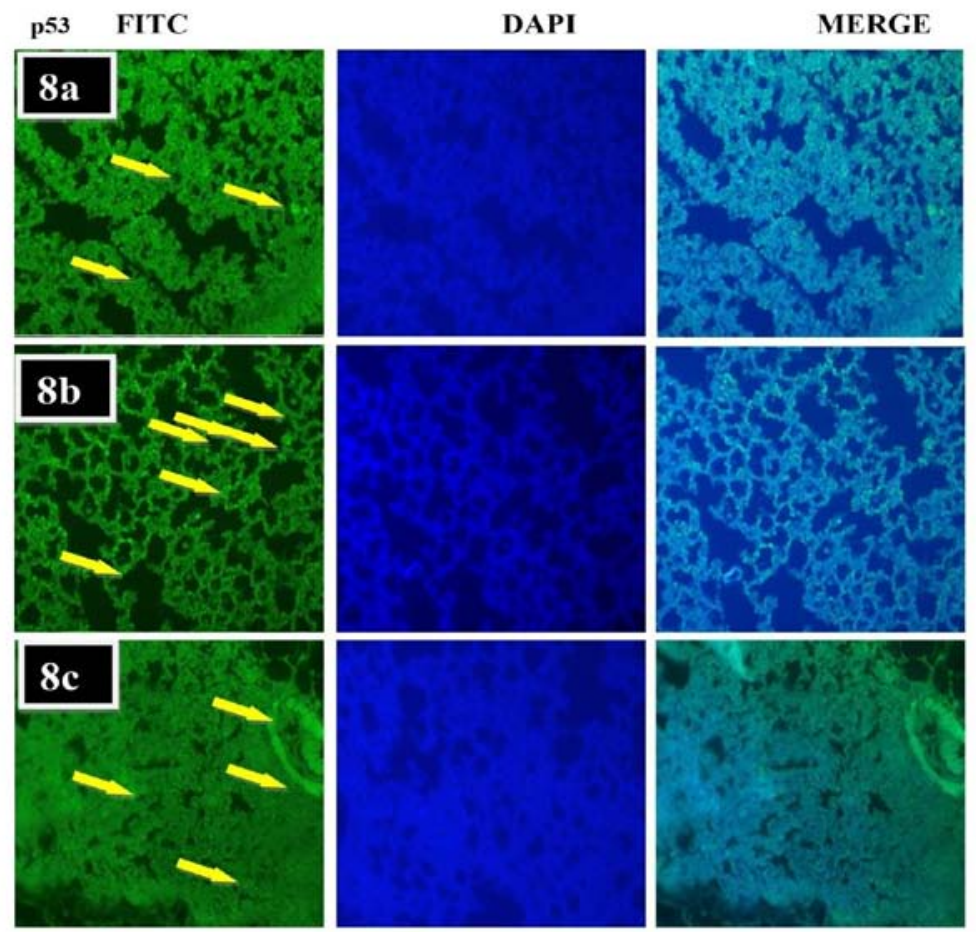

Figure 8: Immunodetection of p53 expression. Intensity of green fluorescence indicates the expression level of p53 at 100x. 8a-Normal mice lung with normal expression of p53.8b - Cancer mice lung with lower expression of p53. 8c - Treated mice lung showing enhanced expression of p53 compared to cancer control. [Magnification - 100x] FITC, DAPI, MERGE [FITC+DAPI].

Caspase 3 MERGE

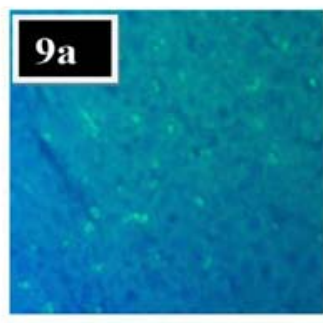

\section{9b}
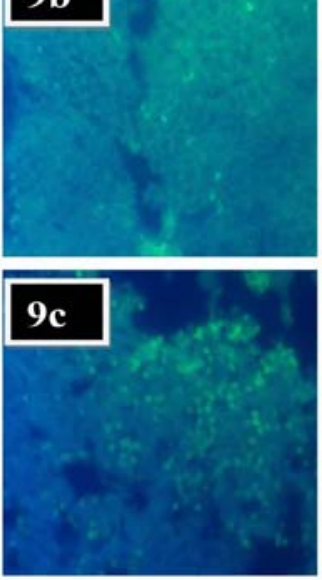

FITC
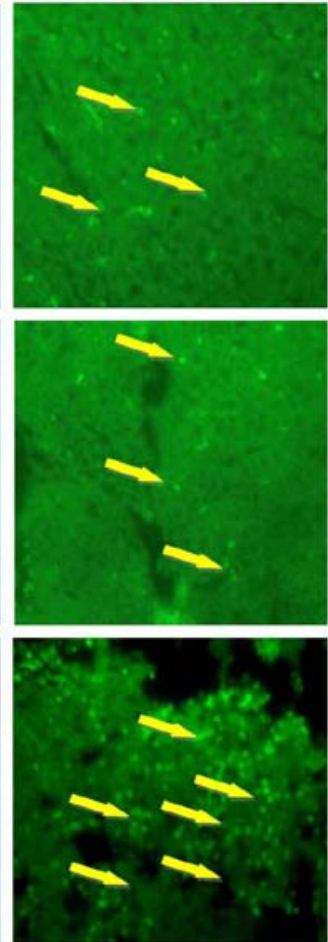

DAPI
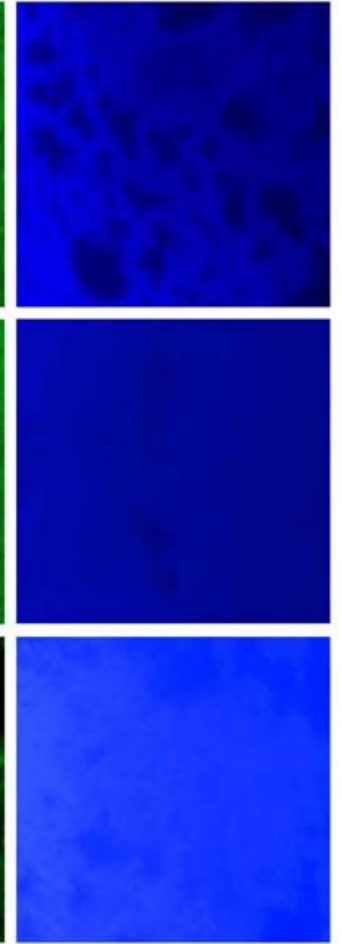

Figure 9: Immunodetection of Caspase 3 expression. Intensity of green fluorescence indicates the expression level of caspase 3 at $100 x$. 9a-Normal mice lung with normal expression of caspase 3. 9b - Cancer mice lung with lower expression of caspase 3. 9c- Lung histology of treated mice showing enhanced expression of caspase 3 compared to cancer control. 


\begin{tabular}{|l|l|l|}
\hline Group & Number of tumor directed capillaries $/ \mathbf{c m}^{2}$ & $\%$ of inhibition \\
\hline Group :1 & $21.48 \pm 0.39$ & - \\
\hline Group :2 & $21.29 \pm 1.37$ & 0.88 \\
\hline Group: $\mathbf{3}$ & $17.33 \mathrm{a} \pm 1.63$ & 19.32 \\
\hline
\end{tabular}

Data are expressed as mean \pm S.D.

Group 1 Vs Group 3 [a: $P \leq 0.01$ ]

Table 3: Effect of essential oil Wedelia chinensis (Osbeck) on tumor directed capillary vessel formation.

chemotherapy regimens and radiotherapy. An earlier report states that the Carvocrol in combination with Thymol will exert an excellent antitumor activity [30]. The present study showed a significant inhibition on tumor nodule formation in the essential oil treated mice which may be because of the major compounds present in the essential oil such as Carvocrol and other compounds. The other indicators of cancer such as decrease in body weight, increase in relative lung weight, increase in WBC and decrease in $\mathrm{Hb}$ count were also observed in our study in lung metastasis too and where found to be reversed in essential oil treated group. The histopathologic report also has shown a curative activity for essential oil treatment.

Angiogenesis, the recruitment of new blood vessels, is an essential component of the metastatic pathway. These newly formed blood vessels provide the gateway through which the tumor cells exit the primary tumor site and enter the circulation [31]. Angiogenesis has been implicated in affecting outcomes in human cancer. Angiogenic factors are found within tumors as well as in such body fluids as serum, urine, and ocular fluids [32]. The major limitations of conventional cancer therapies are that they are often limited in use, by causing regression of tumors that have undergone distant or widespread metastasis. One of the potential advantages of anti-angiogenic therapy is that, at least in experimental animals, anti-angiogenic agents can cause regression of metastatic lesions and also prevent their dissemination [33]. It is of interest that some plant based agents including taxol, tamoxifen, and adriamycin which are already in clinical use as anti-tumor agents are being found to have anti-angiogenic activity [34]. Researchers have reported that most metastases are ultimately to the lung, liver or bone [35]. Therefore, novel agents preventing both the cancer onset and metastatic spreading are urgently required for their treatment. For the past few years, researchers are focusing on Phytochemicals i.e., bioactive compounds isolated from plants, due to their low toxicity and their enormous chemotherapeutic/chemo preventive actions [36]. Our study on essential oil of Wedelia chinensis (Osbeck) has shown a significant reduction in the formation of tumor directed new blood vessels and hence may be considered as one of the anti-angiogenic agent after further studies at molecular level.

In the last decade, basic cancer research has produced remarkable advances in our understanding of cancer biology and cancer genetics. Among the most important of these advances is the realization that apoptosis and the genes that control it have a profound effect on the malignant phenotype. Apoptosis was initially described by its morphological characteristics, including cell shrinkage, membrane blebbing, chromatin condensation and nuclear fragmentation. But, apoptosis and necrosis are two typical types of cell death which has been recognized earlier as a key feature of normal animal development [37]. Apoptosis is characterized by several biochemical criteria such as

changes in mitochondrial membrane permeability, caspase signaling activation, internucleosomal DNA cleavage, and the release of intermembrane mitochondrial proteins [38] and cause cells death by activating a suicide programme that may be regulated by interactions with other cells [39].

Research regarding apoptosis has increased substantially since the early 1990s [40]. In addition to its importance as a biological phenomenon, defective apoptotic processes have been implicated in an extensive variety of diseases including carcinogenesis. In contrast, necrosis is characterized mostly in negative terms by the absence of apoptosis parameters, such as caspase activation [41]. Therefore, it has been suggested that the susceptibility of cancer to chemotherapeutic agents is dependent on the ability of tumor cells to respond to apoptosis. Excessive apoptosis causes atrophy, whereas an insufficient amount results in uncontrolled cell proliferation, such as cancer. TUNEL is a common method for detecting DNA fragmentation that results from apoptotic signaling cascades [42]. On the other hand p53 is a tumor-suppressor protein protects from against cancer by regulating the cellular response to DNA damage, apoptosis, and oncogene activation [43]. The p53 gene is mutated in about half of all human tumors. Usually, p53 protein is present within a cell in minute amounts. It is very labile, with a half-life sometimes as short as a few minutes and hence undetectable. But, mutation makes it stable and detectable in cancer conditions. p53 has many mechanisms of anticancer function, and plays a role in apoptosis, genomic stability, and inhibition of angiogenesis [44]. Caspases are a family of inactive pro enzymes that play a crucial role in cell apoptosis. The role of caspase 3 in apoptosis is to cleave and activate caspases 6,7 and 9 in order to break down the apoptotic cells before removal. After this process, the caspase 3 protein is cleaved and broken down itself by caspase 8 and 10, as well as any inactive caspase 9 proteins that have yet to be cleaved themselves. The sequential cleaving and activation of these proteins is crucial to the execution stage of preprogrammed cellular death [45].

As an executioner caspase, the caspase-3 zymogen has virtually no activity until it is cleaved by an initiator caspase after apoptotic signaling events have occurred. This extrinsic activation then triggers the hallmark caspase cascade characteristic of the apoptotic pathway, in which caspase- 3 plays a dominant role and the activation, function of caspases, involved in the delicate caspase-cascade system, are regulated by various kinds of molecules, such as the inhibitor of apoptosis protein, $\mathrm{Bcl}-2$ family proteins, calpain and $\mathrm{Ca}^{2+}[46]$. In the present study, we have observed an increase in number of apoptotic nuclei in essential oil treated groups which imply that the plant has an apoptosis inducing capability. Consequently, on the other hand, the level of p53 and caspase - 3 expressions were enhanced in essential oil treated group than the cancer group. This implies that the increased levels of p53 and caspase- 3 expressions might have used up for inducing apoptosis. From the above results, the study concludes that the essential oil of Wedelia chinensis (Osbeck) has a significant chemotherapeutic effect on lung metastasis and its associated activities such as apoptosis and angiogenesis. The results should be further studied at the molecular level for detecting the detailed mechanism of the drug in preventing cancer.

\section{Conclusion}

As there is an enormous increase in the population lung cancer incidence day by day, the alternative therapy in the market is getting its 
glimpse. The cheap herbal drug treatment may highly be recommended to the rural and poor people to treat effectively the cancers of various types as an ideal choice or as combinational therapy.

\section{Acknowledgement}

Authors acknowledge the valuable help rendered by Dr. G.V.S. Murthy (Joint Director) Botanical Survey of India - Coimbatore - T.N.A.U Campus, Tamilnadu for identification and authentication of the plant specimens and DR.N.K. Leela (Senior Scientist) - GC-MS Survey, Indian Institute of Spices Research (IISR), Calicut Kerala for GC - MS analysis and validation of the results. Authors acknowledge the valuable suggestions and technical guidance given by Dr. C. Guruvayoorappan, Assistant Professor (SG), Department of Biotechnology, Karunya University, Coimbatore. We acknowledge the scholars Mr. Siddikuzzaman and M/s. D. Ramya for their technical and moral support during the research.

\section{References}

1. Fidler IJ (1978) Tumor heterogeneity and the biology of cancer invasion and metastasis. Cancer Res 38: 2651-2660.

2. Sörenson S, Glimelius B, Nygren P, SBU-group Swedish Council of Technology Assessment in Health Care (2001) A systematic overview of chemotherapy effects in non-small cell lung cancer. Acta Oncol 40: 327-339.

3. Wyke JA (2000) Overview--burgeoning promise in metastasis research. Eur J Cancer 36: 1589-1594.

4. Fan TP, Yeh JC, Leung KW, Yue PY, Wong RN (2006) Angiogenesis: from plants to blood vessels. Trends Pharmacol Sci 27: 297-309.

5. Kerr JF, Wyllie AH, Currie AR (1972) Apoptosis: a basic biological phenomenon with wide-ranging implications in tissue kinetics. Br J Cancer 26: 239-257.

6. Sullivan R, Smith JE, Rowan NJ (2011) Ethno medicinal Plants for Cancer Therapy - A Review. Hygeia J D Med 3: 1-10.

7. Gould MN (1995) Prevention and therapy of mammary cancer by monoterpenes. J Cell Biochem Suppl 22: 139-144.

8. Meena AK, Rao MM, Meena RP, Panda P (2011) Pharmacological and phytochemical evidences for the plants of Wedelia Genus-A Review. Asian J Pharm Res 1: 7-12.

9. Manjamalai A, Jiflin GJ, VM Berlin grace (2012) Study on the effect of essentia oil of Wedelia chinensis (Osbeck) against microbes and inflammation. Asian Pac J Cancer Prev 5: 155-163.

10. Bhushankumar P, Vichiksha RS, Supriya AB (2012) Anti-proliferative effects of Carvocrol on human prostate cancer cell line LNCaP. The FASEB Journal 26: $1037-1045$

11. Sureshkumar SH, Sivakumar T, Chandrasekar MNJ, Suresh B (2006) Investigating the anti-inflammatory and analgesic activity of leaves of Wedelia chinensis (Osbeck) in standard experimental animal. Iran J Pharm Res 2: 123129

12. Tsai CH, Lin FM, Yang YC, Lee MT, Cha TL, et al. (2009) Herbal extract of Wedelia chinensis attenuates androgen receptor activity and orthotopic growth of prostate cancer in nude mice. Clin Cancer Res 15: 5435-5444.

13. Mahavorasirikul W, Viyanant $V$, Chaijaroenkul W, Itharat A, Na-Bangchang K (2010) Cytotoxic activity of Thai medicinal plants against human cholangiocarcinoma, laryngeal and hepatocarcinoma cells in vitro. BMC Complem Altern Med 10: 10-55

14. Akrout A, Gonzalez LA, El Jani H, Madrid PC (2011) Antioxidant and antitumor activities of Artemisia campestris and Thymelaea hirsuta from southern Tunisia. Food Chem Toxicol 49: 342-347.

15. Bhagwat DA, Killedar SG, Adnaik SG (2008) Antidiabetic activity of leaf extract of Tridax procumbens L. Int J Green Pharm 2: 126 -128.

16. Guimarães FS, Andrade LF, Martins ST, Abud AP, Sene RV, et al. (2010) Guimaraes. In vitro and in vivo anticancer properties of a Calcarea carbonica derivative complex (M8) treatment in a murine melanoma model. BMC Cancer 10: $1-14$

17. Sheeja K, Kuttan G (2010) Andrographis paniculata downregulates proinflammatory cytokine production and augments cell mediated immune response in metastatic tumor-bearing mice. Asian Pac J Cancer Prev 11: 723 729

18. Mosmann T (1983) Rapid colorimetric assay for cellular growth and survival: application to proliferation and cytotoxicity assays. J Immunol Methods 65: 5563.

19. Preethi KC, Siveen KS, Kuttan R, Kuttan G (2010) Inhibition of metastasis of B16F-10 melanoma cells in C57BL/6 mice by an extract of Calendula officinalis L flowers. Asian Pac J Cancer Prev 11: 1773-1779.

20. Kumar MJ, Ponvijay KS, Nandhini R, Nagarajan RS, Jose J, et al. (2007) A mouse model for luminal epithelial like ER positive subtype of human breast cancer. BMC Cancer 7: 180.

21. Gopal K, Kumar K, Nandini R, Jahan P, Kumar MJ (2010) High fat diet containing cholesterol induces aortic aneurysm through recruitment and proliferation of circulating agranulocytes in apoE knockout mice model. J Thromb Thrombolysis 30: 154-163.

22. Yau Hsiung W, Abdul Kadir $\mathrm{H}$ (2011) Leea indica ethylacetate fraction induces growth-inhibitory effect in various cancer cell lines and apoptosis in ca sk human cervical epidermoid carcinoma cells. Evid Based Complement Alternat Med 11: 1-13.

23. Gopal K, Nagarajan P, Raj TA, Jahan P, Ganapathy HS, et al. (2011) Effect of dietary $\hat{~}^{2}$ carotene on cerebral aneurysm and subarachnoid haemorrhage in the brain apo E-/- mice. J Thromb Thrombolysis 32: 343-355

24. Yan X, Lin Y, Yang D, Shen Y, Yuan M, et al. (2003) A novel anti-CD146 monoclonal antibody, AA98, inhibits angiogenesis and tumor growth. Blood 102: 184-191.

25. Manjamalai A, Shana AS, VM Berlin Grace (2011) Evaluation of antifungal and anti-inflammatory effect on methanolic extract of Wedelia chinensis leaves. Int J Pharm Biomed Res 3: 30-37.

26. Du WX, Olsen CW, Avena-Bustillos RJ, McHugh TH, Levin CE, et al. (2008) Storage stability and antibacterial activity against Escherichia coli 0157:H7 of carvacrol in edible apple films made by two different casting methods. J Agric Food Chem 56: 3082-3088.

27. Hotta M, Nakata R, Katsukawa M, Hori K, Takahashi S, et al. (2010) Carvacrol, a component of thyme oil, activates PPARalpha and gamma and suppresses COX-2 expression. J Lipid Res 51: 132-139.

28. Bakkali F, Averbeck S, Averbeck D, Idaomar M (2007) Biological effects of essential oils - A review. Food and Chem Toxicol 46: 446-475.

29. BS Shylesh, S Ajikumaran Nair, A Subramoniam (2005) Induction of cellspecific apoptosis and protection from Dalton's lymphoma challenge in mice by an active fraction from Emilia sonchifolia. Indian J pharmacol 37: 232-237.

30. Mezzoug N, Elhadri A, Dallouh A, Amkiss S, Skali NS, et al. (2007) Investigation of the mutagenic and antimutagenic effects of Origanum compactum essentia oil and some of its constituents. Mutat Res 629: 100-110

31. Tapper D, Langer R, Bellows AR, Folkman J (1979) Angiogenesis capacity as a diagnostic marker for human eye tumors. Surgery 86: 36-40.

32. Folkman J (1996) Fighting cancer by attacking its blood supply. Sci Am 275 150-154.

33. Belotti D, Vergani V, Drudis T, Borsotti P, Pitelli MR, et al. (1996) The microtubule-affecting drug paclitaxel has antiangiogenic activity. Clin Cancer Res 2: 1843-1849.

34. D'Incalci M, Steward WP, Gescher AJ (2005) Use of cancer chemopreventive phytochemicals as antineoplastic agents. Lancet Oncol 6: 899-904.

35. de Kok TM, van Breda SG, Manson MM (2008) Mechanisms of combined action of different chemopreventive dietary compounds: a review. Eur J Nutr 47 Suppl 2: 51-59.

36. Eichhorn ME, Kleespies A, Angele MK, Jauch KW, Bruns CJ (2007) Angiogenesis in cancer: molecular mechanisms, clinical impact. Langenbecks Arch Surg 392: 371-379.

37. Raff MC (1992) Social controls on cell survival and cell death. Nature 356 397-400. 
Citation: Manjamalai A, Grace B (2013) Chemotherapeutic Effect of Essential Oil of Wedelia chinensis (Osbeck) on Inducing Apoptosis, Suppressing Angiogenesis and Lung Metastasis in C57BL/6 Mice Model. J Cancer Sci Ther 5: 271-281. doi:10.4172/1948-5956.1000216

38. Wyllie AH, Kerr JF, Currie AR (1980) Cell death: the significance of apoptosis. Int Rev Cytol 68: 251-306.

39. Thornberry NA, Lazebnik Y (1998) Caspases: enemies within. Science 281: $1312-1316$.

40. Kitanaka C, Kuchino Y (1999) Caspase-independent programmed cell death with necrotic morphology. Cell Death Differ 6: 508-515.

41. Williams GT (1991) Programmed cell death: apoptosis and oncogenesis. Cell 65: $1097-1098$

42. Kastan MB, Onyekwere O, Sidransky D, Vogelstein B, Craig RW (1991) Participation of p53 protein in the cellular response to DNA damage. Cancer Res 51: 6304-6311.
43. Levine AJ (1997) p53, the cellular gatekeeper for growth and division. Cell 88 323-331.

44. Walters J, Pop C, Scott FL, Drag M, Swartz P, et al. (2009) A constitutively active and uninhibitable caspase- 3 zymogen efficiently induces apoptosis. Biochem J 424: 335-345

45. Gallaher BW, Hille R, Raile K, Kiess W (2001) Apoptosis: live or die--hard work either way! Horm Metab Res 33: 511-519.

46. Katunuma N, Matsui A, Le QT, Utsumi K, Salvesen G, et al. (2001) Nove procaspase- 3 activating cascade mediated by lysoapoptases and its biological significances in apoptosis. Adv Enzyme Regul 41: 237-250. 